\title{
CONTEKTUAL TEACHING LEARNING: ALTERNATIF MODEL PEMBELAJARAN DALAM MENINGKATKAN PEMAHAMAN KONSEP IPA SISWA SD DI PURWAKARTA
}

\author{
Hany Handayani ${ }^{1}$, Riska ${ }^{2}$, Wiwin Winarti ${ }^{3}$,Indra Suhendra ${ }^{4}$ \\ 1,2,3STKIP Purwakarta, ${ }^{4}$ Universitas Pendidikan Indonesia \\ 1Hanyhandayani011117@gmail.com, ${ }^{2}$ khariska@gmail.com, \\ 303wiwin@gmail.com, ${ }^{4}$ indrasuhendra@upi.edu
}

\begin{abstract}
This research aims to know the influence of contextual learning model (contextual learning) against the concept of understanding IPA grade IV, these studies use quantitative methods with quasi (quasi experimental approach experiments), in this study used two groups of subjects, namely group wants and the control group. Data collection techniques in the study using four techniques include understanding tests (pretest and posttest) observation sheets performance, teacher, and student performance observation sheets. As for the results of statistical tests on the extent of $\alpha=0.05$ significant results as follows: 1) pretest results understanding of student groups and experiments kontrok obtained by the $P$-value of 0.125 to mean there are no differences among the capabilities experimental and control groups of students, posttest results, 2) value of understanding IPA students after the class action on the given experiment obtained $P$ value 0.000-meaning there are contextual learning model of influence towards the understanding of the concept of science in students, 3) observations of performance the teacher showed the results of the average $81.85 \%$ (very good) that shows the performance of teachers already balanced and optimum support of successful learning, and 4 student activity observation) results obtained average results $89.85 \%$ (very good) indicate that from each of the indicators approach CTL terintrepetasi is very good.
\end{abstract}

Key words: Contextual Learning, IPA in elementary school, understanding the concept

\section{ABSTRAK}

Penelitian ini bertujuan untuk mengetahui pengaruh model pembelajaran kontekstual (contextual learning) terhadap pemahaman konsep IPA siswa kelas IV, penelitian ini menggunakan metode kuantitatif dengan pendekatan eksperimen semu (kuasi eksperimen), dalam penelitian ini menggunakan dua kelompok subjek yaitu kelompok ekperimen dan kelompok kontrol. Teknik pengumpulan data dalam penelitian ini menggunakan empat teknik diantaranya tes pemahaman konsep (pretest dan posttest), lembar observasi kinerja guru, dan lembar observasi kinerja siswa. Adapun hasil dari uji statistik pada taraf signifikan $\alpha=0,05$ hasilnya sebagai berikut: 1) hasil pretest pemahaman konsep siswa kelompok eksperimen dan kontrok didapatkan $P$-value sebesar 0,125 yang artinya tidak terdapat perbedaan kemampuan awal antara kelompok siswa eksperimen dan kontrol, 2) hasil posttest nilai pemahaman konsep IPA siswa setelah diberikan tindakan pada kelas 
eksperimen didapatkan $P$-value 0,000 yang artinya terdapat pengaruh model pembelajaran kontekstual terhadap pemahaman konsep IPA pada siswa, 3) hasil observasi kinerja guru menunjukan hasil rata-rata $81,85 \%$ (sangat baik) yang menunjukan kinerja guru sudah seimbang dan optimal mendukung berhasilnya pembelajaran, dan 4) hasil observasi aktivitas siswa didapatkan hasil rata rata $89,85 \%$ (sangat baik) menunjukan bahwa dari setiap indikator penekatan CTL terintrepetasi sangat baik.

Kata Kunci: Pembelajaran Kontekstual, IPA di Sekolah Dasar, Pemahaman Konsep

\section{A. Pendahuluan}

IPA merupakan mata pelajaran yang mulai diajarkan di sekolah dasar (SD) sampai perguruan tinggi (PT) (Nurdyansyah, 2016). Salah satu tujuan pembelajaran IPA yang tertuang dalam (Pendidikan, 2006) adalah mengembangkan pengetahuan dan konsep-konsep IPA yang bermanfaaat dan dapat diterapkan dalam kehidupan seharihari. Hal tersebut sejalan dengan yang diungkapkan oleh (Sujana, 2014) yang menyebutkan bahwa pembelajaran IPA di sekolah dasar (SD) khususnya harus menekankan kepada pemberian pengalaman langsung untuk mengembangkan kompetensi siswa agar dapat menjelajahi dan memahami alam sekitar secara ilmiah. Hal tersebut disebabkan karena IPA sangat diperlukan dalam kehidupan seharihari untuk memenuhi berbagai kebutuhan hidup manusia. Dengan melihat salah satu tujuan pembelajaran IPA tersebut diharapkan siswa dapat memiliki dan mengembangkan kompetensi yang dimilikinya (Taufiq, Dewi, \& Widiyatmoko, 2014).

$$
\text { Salah satu diantaranya }
$$
kompetensi yang harus dimiliki dan dikembangkan oleh siswa dalam pembelajaran IPA adalah pemahaman konsep. Pemahaman konsep merupakan salah satu tujuan dalam pembelajaran IPA (Laksana \& Wawe, 2015). Hal tersebut sesuai dengan tujuan yang diharapkan dari pembelajaran IPA oleh (Permendiknas, 2006) yang menekankan penguasaan kompetensi melalui proses ilmiah yang mengembangkan keterampilan proses, pemahaman konsep, aplikasi konsep, sikap ilmiah, serta mendasarkan kegiatan pembelajaran pada isu-isu yang sedang berkembang di masyarakat. 
Dengan melihat fakta yang ada di Indonesia bahwa kompetensi siswa dalam memahami konsep pembelajaran IPA masih sangat kurang. Hasil penelitian (Bybee, 2009) dalam program PISA (Programme for International Student Assessment) yang diselenggarakan oleh OECD (Organization for Economy Cooperationand Development) pada tahun 2012 Indonesia ada peringkat ke 64 dari 65 negara dengan skor 382.

Berdasarkan fakta tersebut selain harus ada upaya peningkatan pemahaman konsep IPA siswa, tentu hal yang tidak kalah penting adalah peningkatan kinerja guru dalam proses pembelajaran di dalam kelas. Karena salah satu faktor yang menentukan keberhasilan belajar siswa dalam memahami konsep pembelajaran IPA adalah kinerja guru selama proses pembelajaran dimana guru harus mamou mengubah pembelajaran IPA yang abstrak menjadi konkret, yang semula sulit menjadi mudah, dan tidak bermakna menjadi bermakna (Wisudawati \& Sulistyowati, 2014).
Salah satu alternatif untuk meningkatkan pemahaman siswa

\section{B. Landasan Teori}
1. Pemahaman konsep IPA

terhadap materi dalam pembelajaran IPA adalah dengan menerapkan model CTL (contextual learning) (Hasibuan, 2015), dimana dengan menerapkan model tersebut diharapkan memberikan pengalaman yang berbeda kepada siswa ketika melaksanakan pembelajaran IPA. Hal tersebut sejalan dengan yang diungkapkan (Sanjaya, 2006) yang mengungkapkan bahwa pendekatan CTL adalah "suatu pendekatan pembelajaran yang menekankan kepada proses keterlibatan siswa secara penuh untuk dapat menemukan materi yang dipelajari dan menghubungkannya dengan situasi kehidupan nyata sehingga mendorong siswa untuk dapat menerapkannya dalam kehidupan mereka".

Oleh karena itu dalam penelitian ini bertujuan untuk mengetahui respon siswa sebelum menggunakan model pembelajaran kontekstual dan setelah menggunakan model pembelajaran kontekstual. Serta ketepatan kinerja guru dalam pengaplikasian model pembelajaran kontekstual. 
Pemahaman adalah suatu proses mental yang terjadi ketika terdapat adaptasi dan transformasi ilmu pengetahuan (Hearron, 2000). Selajutnya dalam (Margunayasa, 2014) menyatakan berdasarkan taksonomi Gagne, pemahaman berada pada level informasi verbal, menurut taksonomi Bloom pada level comprehension, menurut (Krathwohl \& Anderson, 2009) dalam taksonomi Anderson pemahaman itu terdapat pada level pengetahuan deklaratif, berdasarkan taksonomi Merril pada lever remember paraphased, dan menurut taksonomi Reigeluth pada level memahami hubungan-hubungan (Reigeluth \& Moore, 1999).

Selanjutnya menurut (Uno, 2007) pemahaman adalah "kemampuan seseorang dala mengartikan, menafsirkan, menerjemahkan atau menyatakan sesuatu dengan caranya sendiri tentang pengetahuan yang pernah diterimanya". Sedangkan menurut (Suhana, 2014) mengatakan pemahaman adalah kemampuan menangkap pengertian, menerjemahkan dan menafsirkan. Konsep menurut (Singarimbun \& Effendi, 1995) menjelaskan konsep sebagai "abstraksi mengenai suatu fenomena yang dirumuskan atas dasar generalisasi atas sejumlah karakteristik kejadian, keadaan, kelompok atau individu tertentu". sedangkan menurut Walgito dalam (Rafika, 2014) menjelaskan bahwa konsep adalah konstruksi simbolik yang menggambarkan ciri-ciri suatu objek atau kejadian. Pendapat lain diungkapkan Noviyana dalam (Aulia \& Handayani, 2018) bahwa pemahaman konsep merupakan kemampuan peserta didik dalam mengartikan suatu konsep dan mengaplikasikan hasil dari belajar tersebut dalam setiap situasi dalam pemecahan masalah.

Dari pemaparan di atas dapat disimpulkan bahwa pemahaman konsep adalah kemampuan siswa dalam mengartikan suatu kejadian, pemahaman juga berarti kecakapan seseorang untuk mengerti akan konsep dan prosedur. Oleh karena itu siswa mampu menjelaskan kembali sesuai dengan pengetahuan yang telah didapatkan dan menghubungkannya melalui sudut pandang yang lain.

Selanjutnya (Anderson \& Krathwohl, 2010) mengemukakan 
terdapat tujuh indikator pemahaman konsep yaitu

a) menafsirkan; mencontohkan; c) mengklasifikasi; d) merangkum; e) menyimpulkan; f) membandingkan; dan g) menjelaskan.

\section{Pengertian Pendidikan IPA}

Menurut (Widyatiningtyas, 2006) pendidikan IPA atau ilmu sains merupakan upaya pemahan, penyadaran, dan pengembangan nilai positif tentang hakekat sains melalui pembelajaran. Pada hakikatnya IPA merupakan ilmu dan pengetahuan tentang fenomena alam yang meliputi produk dan proses.

Pendidikan IPA merupakan salah satu aspek pendidikan yang menggunakan sains sebagai alat untuk mencapai tujuan pendidikan, yakni untuk meningkatkan pengertian terhadap dunia alamiah, Menurut Einstein (Sujana, 2014) IPA mengandung nilai-nilai intrinsic seperti nilai prolestis, nilai intelektual, nilai sosiopolitik, serta nilai religi. Sehingga, dalam praktik pembelajaran IPA harus ada hubungannya dalam kehidupan sehari-hari serta harus bermuatan nilai untuk mencegah dan mengatasi terjadinya kemerosotan nilai pada suatu bangsa.

\section{Pendekatan Contextual}

\section{Teaching and Learning (CTL)}

Pembelajaran kontekstual merupakan konsep yang memfasilitasi guru dalam menghubungkan antara materi pembelajaran dengan kehidupan siswa (Amir, 2015). Pendapat yang lain menurut (Slavin, 2011) selain menghubungkan materi dengan kehidupan nyata siswa juga dapat mendorong siswa untuk menghubungkan antara pengetahuan awal yang dimilikinya dengan penerapannya dalam kehidupan siswa sebagai anggota keluarga juga masyarakat.

Menurut (Johnson, 2007) penemuan makna adalah ciri utama dari pembelajaran kontekstual, makna ini dapat diartikan apabila siswa menghubungkan muatan akademik dengan konteks kehidupan sehari-hari mereka. konteks dalam hal ini dapat dipahami sebagai pola hubunganhubungan didalam lingkaran langsung siswa. menurut (Sujana, 2014) model pembelajaran kontekstual merupakan model pembelajaran yang mengaitkan materi pembelajaran yang dengan kehidupan sehari-hari. Sedangkan menurut (Aqib, 2013) pendekatan kontekstual merupakan konsep 
belajar yang membantu guru mengaitkan antara materi yang diajarkan dengan situasi dunia nyata siswa dan mendorong siswa membuat hubungan antara pengetahuan yang dimilikinya dengan penerapannya dalam kehidupan mereka sebagai anggota keluarga dan masyarakat. Pendapat yang sama disampaikan oleh Zainal dalam (Sanjaya, 2006) menyatakan bahwa Contextual Teaching and Learning (CTL) adalah suatu pendekatan pembelajaran yang menekankan kepada proses keterlibatan siswa secara penuh untuk dapat menemukan materi yang dipelajari dan menghubungkannya dengan situasi kehidupan nyata sehingga mendorong siswa untuk dapat menerapkannya dalam kehidupan mereka.

Dari beberapa definisi pendekatan Contextual Teaching and Learning (CTL) menurut para ahli dapat ditarik kesimpulan bahwa pendekatan Contextual Teaching and Learning (CTL) adalah suatu pendekatan pembelajaran yang menekankan pada proses keterlibatan siswa pada proses pembelajaran dan mengaitkan secara langsung dengan kehidupan sehari-hari.
Menurut Trianto dalam (Sujana, 2014) terdapat tujuh tahapan yang harus dilakukan dala praktik pengembangan model pembelajaran konstektual yaitu a) mengembangkan pemikiran bahwa siswa akan belajar bermakna melalui bekerja sendiri, menemukan sendiri serta mengkontruksi pengetahuan dan keterampilan baru; b) melaksanakan kegiatan ikuiri seoptimal mungkin; c) mengembangkan sifat ingin tahu siswa melalui kegiatan bertanya; d) menciptakan masyarakat belajar yang baik; e) hindari model sebagai contoh pembelajaran; f) melakukan refleksi di akhir pertemuan; dan g) melakukan penialian yang sebenarnya melalui berbagai cara.

\section{Metode Penelitian}

1. Desain

Penelitian ini merupakan penelitian kuantitatif dengan pendekatan eksperimen semu (quasi experimental) karena penelitian ini dilakukan pada lingkugan sekolah dengan telah ditentukan sampel penelitiannya yaitu siswa kelas IV SDN 2 Sukjaya.

Adapun desain penelitian ekperimen pada penelitian ini adalah 
pretest-posttest control group design (Campbell \& Stanley, 2015). Dimana penelitian ini menggunakan dua kelompok subjek, pertama kelompok eksperimen dan yang kedua adalah kelompok kontrol. Pada awalnya kedua kelompok tersebut akan mendapatjan tes awal (pretest). Selanjutnya, pada kelas eksperimen menerima perlakukan berupa pembelajaran model CTL, sedangkan pada kelompok kontrol tidak mendapatkan perlakuan apapun atau hanya melaksanakan pembelajaran langsung. Setelah tahap perlakukan selanjutnya pada kedua kelompok tersebut diberikan tes untuk mengukur keteampilan menulis karangan narasi siswa berupa tes (posttest), desain penelitian ini dapat dilihat pada tabel 1 sebagai berikut.

Tabel 1 Desain Penelitian

\begin{tabular}{llll} 
Kelompok & PreTest & Perlakuan & PostTest \\
\hline E & O1 & $\mathrm{X}$ & O2 \\
\hline K & O3 & - & O4
\end{tabular}

Keterangan :

$\mathrm{E} \quad$ : kelompok eksperimen

$\mathrm{K}$ : kelompok kontrol

$\mathrm{X} \quad$ : perlakuan pada kelas eksperimen (menggunakan model write and move berbasis literasi digital)

O1 : Pre Test kelompok eksperimen

O2 : Post Test kelompok eksperimen

O3 : Pre Test kelompok kontrol

O4 : Post Test kelompok kontrol

\section{Teknik Pengumpulan Data}

Teknik pengumpulan data yang digunakan oleh peneliti untuk mendapatkan data pada kelas IV (empat) di salah satu SD di Purwakarta sebagai subjek peneliti dengan menggunakan empat teknik pengumpulan data yaitu tes pemahaman konsep, lembar observasi kinerja guru dan lembar observasi aktivitas siswa.

\section{Prosedur Penelitian}

Dalam prosedur pelaksanaan penelitian ini, diawali dengan peneliti pertama, peneliti melakukan pretest yang dikakukan pada kelas eksperimen dan kelas kontrol untuk mengetahui kemampuan pemahaman konsep pembelajaran IPA sebelum diberikan treatment. Pretest dilaksanakan pada hari Kamis tanggal 27 April 2017. Pretest ini diikuti oleh seluruh siswa, baik kelas eksperimen maupun kelas kontrol yang masingmasing kelas terdiri dari 35 siswa. Soal yang digunakan pada pretest yaitu soal yang telah di uji cobakan terlebih dahulu dan telah mendapatkan judgement dari para ahli (dosen STKIP Purwakarta). Data yang diperoleh dari hasil Pretest kemudian diolah sehingga diketahui nilai ratarata (mean), nilai tertinggi, nilai 
terendah, dan standar deviasi dari setiap kelas.

Pada pertemuan berikutnya siswa diberikan pembelajaran menggunakan model pembelajaran kontekstual. Setelah diberikan treatment, selanjutnya dilakukan posttest untuk mengetahui kemampuan pemahaman konsep pembelajaran IPA. Setelah siswa diberikan treatment berikutnya dilakukan posttes yaitu kelas kontrol. Sementara, pada kelas eksperimen dilaksanakan sehari setelahnya. Posttet ini diikuti oleh seluruh siswa, baik kelas eksperimen maupun kelas kontrol yang masing-masing kelas terdiri dari 35 siswa. Soal yang digunakan pada posttest sama persis dengan soal yang digunakan pada saat pretes.

Setelah diperoleh data hasil pretest dan posttest, selanjutnya data dianalisis. Analisis hasil penelitian dilakukan menggunakan uji normalitas, uji homogenitas dan Uji $t$. Dalam pengolahan datanya, peneliti menggunakan program SPSS 2.3 for Windows.

Uji $t$ digunakan untuk melihat perbedaan kemampuan akhir pemahaman konsep IPA siswa pada kelas eksperimen dan siswa pada kelas kontrol terdapat pengaruh penggunaan CTL terhadap pemahaman konsep IPA.

\section{Hasil Penelitian dan Pembahasan}

Berikut adalah paparan hasil atau temuan dari penelitian yang dilakukan oleh peneliti, mulai dari paparan data pretest, postest, dan analisis hasil observasi bail itu kinerja guru ataupun aktivitas siswa dengan menggunakan program SPSS 23 for windows sebagai berikut:

\section{Analisis Data Pretest}

Uji hipotesis langsung dilakukan atau tidak melakukan uji homogenitas terlebih dahulu karena data pretest yang diperoleh dari kedua kelas berdistribusi tidak normal. Uji perbedaan rata-rata dilakukan untuk mengetahui kemampuan awal kelas eksperimen dan kelas kontrol. Uji perbedaan rata-rata yang digunakan adalah uji nonparametrik ManWhitney (Uji-U) pada taraf signifikansi $\alpha=0,05$. Uji ini dilakukan untuk menguji perbedaan rata-rata kedua kelas yang salah satu atau keduanya berdistribusi tidak normal. Adapun 
hipotesis yang diuji yaitu sebagai berikut.

$\mathrm{H}_{0}=$ tidak terdapat perbedaan kemampuan awal antara siswa pada kelas eksperimen dan pada siswa kelas kontrol.

$\mathrm{H}_{1}=$ terdapat perbedaan kemampuan awal antara siswa pada kelas eksperimen dan pada siswa kelas kontrol.

Kriteria pengujiannya yaitu $\mathrm{H}_{0}$ diterima apabila nilai $P$-value (Sig.2tailed) lebih atau sama dengan 0,05 dan $\mathrm{H}_{0}$ ditolak apabila nilai $P$-value (Sig.2-tailed) kurang dari 0,05. Perhitungan uji Mann-Whitney ini menggunakan bantuan program SPSS 2.3 for Windows. Data hasil perhitungan tersebut dapat dilihat pada tabel 2 sebagai berikut.

Tabel 2

Hasil Uji Mann-Whitney Data Pretest

Test Statistics $^{a}$

\begin{tabular}{lr}
\hline & Pemahaman_Konsep \\
\hline Mann-Whitney U & 482,500 \\
\hline Wilcoxon W & 1112,500 \\
\hline$Z$ & $-1,537$ \\
\hline Asymp. Sig. (2-tailed) &, 124 \\
\hline
\end{tabular}

a. Grouping Variable: Kelas

Tabel 2 dapat dilihat bahwa hasil perhitungan perbedaan rata-rata pretest kelas eksperimen dan kelas kontrol dengan menggunakan uji nonparametrik Mann-Whitney (Uji-U) dengan taraf signifikansi $a=0,05$ didapatkan P-value (Sig.2-tailed) sebesar 0,124. Hal ini menunjukkan bahwa $\mathrm{H}_{0}$ yaitu tidak terdapat perbedaan kemampuan awal antara siswa pada kelas eksperimen dan siswa pada kelas kontrol diterima. Dengan demikian, tidak terdapat perbedaan kemampuan awal antara kelas eksperimen dan kelas kontrol

\section{Analisis Data Postest}

Berdasarkan uji normalitas dan uji homogenitas, data posttest kemampuan pemahaman konnsep IPA siswa menunjukkan normal dan homogen. Oleh karena itu, selanjutnya dilakukan uji hipotesis dengan menggunakan uji-t unuk sampel bebas. Adapun hipotesis yang diuji yaitu sebagai berikut.

$\mathrm{H}_{0}=$ tidak terdapat pengaruh penggunaan pendekatan CTL tehadap pemahaman konsep IPA. $\mathrm{H}_{1}=$ terdapat pengaruh penggunaan pendekatan CTL terhadap pemahaman konsep IPA.

Kriteria pengujiannya dengan menggunakan taraf signifikan 5\% ( $\alpha=$ 0,05) berdasarkan $P$-value. Kriteria pengujiannya yaitu jika $P$-value $<0,05$, maka $\mathrm{H}_{0}$ ditolak dan jika $P$-value $\geq$ 0,05, maka $\mathrm{H}_{0}$ diterima. Adapun hasil perhitungan perbedaan rata-rata 
menggunakan uji-t dapat dilihat pada tabel 3 sebagai berikut.

Tabel 3

Analisis Uji-t Data Posttest Kemampuan

Pemahaman Konsep IPA

Independent Samples Test

\begin{tabular}{|c|c|c|c|c|}
\hline & \multicolumn{4}{|c|}{ t-test for Equality of Means } \\
\hline & \multirow[b]{2}{*}{$\mathrm{Si}$} & \multicolumn{3}{|c|}{$95 \%$} \\
\hline & & & & Confidenc \\
\hline & g. & & & e Interval \\
\hline & $(2-$ & Mea & Std. & of the \\
\hline & tail & $\mathrm{n}$ & Error & Difference \\
\hline & d ed & Differ & Differ & Low Upp \\
\hline $\mathrm{T}$ & $f \quad$ ) & ence & ence & er er \\
\hline
\end{tabular}

Nilai Equ

Pos al

\begin{tabular}{rrrrrrrrr} 
ttest & varia & 6, & 6 & 0 & 20,5 & 3,37 & 13,8 & 27,3 \\
nces & 08 & 8 & 00 & 7143 & 831 & 301 & 127 \\
assu & 9 & & & & & 2 & 4 \\
mes & & & & & & & \\
\hline
\end{tabular}

Equ

al

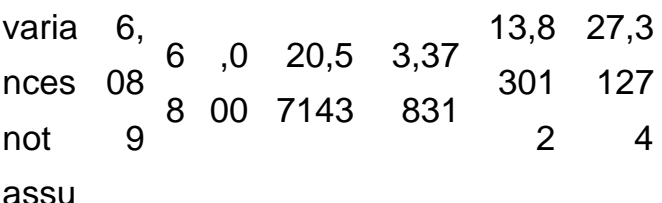

mes

Tabel 3 menunjukkan bahwa

rata-rata kemampuan akhir

pemahaman konsep IPA siswa kelas

eksperimen dan kelas kontrol

berbeda. Hal ini dapat dilihat dari $P$ value (Sig. 2 tailed) yang diperoleh yaitu 0,000 yang berarti kurang dari taraf signifikan 0,05 . Oleh karena itu, $\mathrm{H}_{0}$ ditolak. Artinya, kemampuan akhir pemahaman konsep IPA siswa pada kelas eksperimen dan siswa pada kelas kontrol terdapat pengaruh penggunaan CTL terhadap pemahaman konsep IPA.

\section{Analisis Hasil Observasi Kinerja}

\section{Guru}

Observasi kinerja guru ini dilakukan pada setiap pertemuan oleh observer yang merupakan wali kelas IV di SDN 2 Sukajaya. Untuk lebih jelasnya, data lengkap hasil observasi kinerja guru pada kelas eksperimen dapat dilihat di lampiran. Adapun rekapitulasi hasil observasi kinerja guru dari setiap indikator pendekatan CTL di kelas eksperimen dapat dilihat pada tabel 4 sebagai berikut.

Tabel 4

Rekapitulasi Persentase Hasil Observasi Kinerja Guru

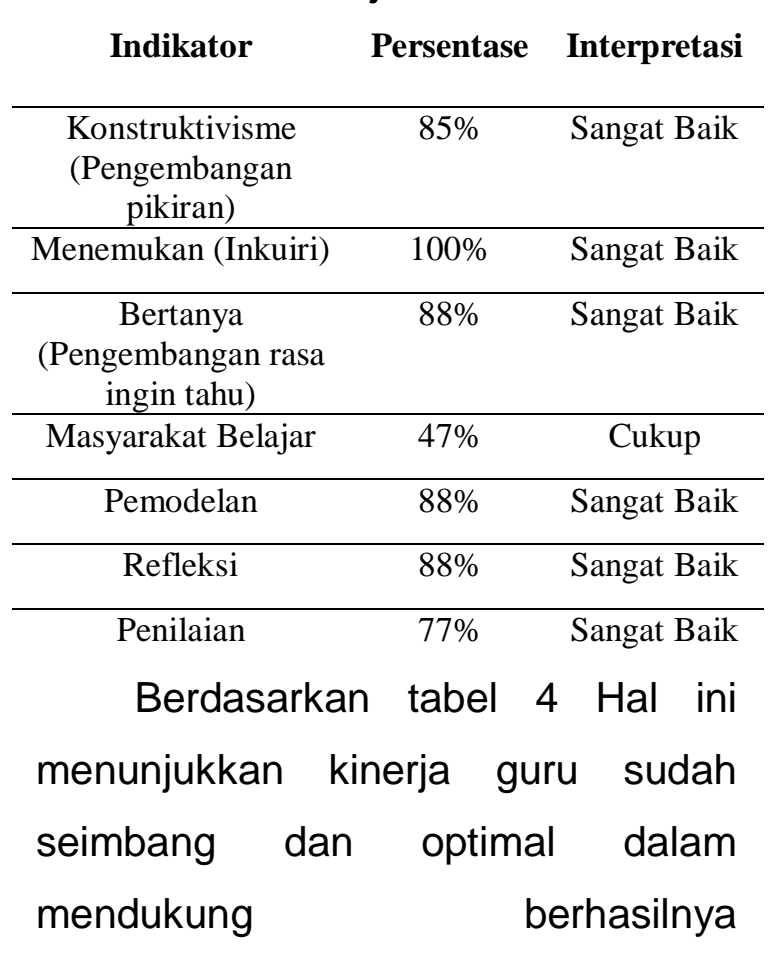

pembelajaran. Berdasarkan analisis 
tersebut, dapat disimpulkan pembelajaran menggunakan pendekatan kontekstual dapat meningkatkan kemampuan pemahaman konsep siswa. Peningkatan tersebut didukung oleh kinerja guru yang optimal mulai dari perencanaan hingga pelaksanaan pembelajaran.

\section{Analisis Hasil Observasi}

\section{Aktivitas Siswa}

Adapun rekapitulasi hasil observasi aktivitas siswa dari setiap indikator pendekatan CTL di kelas eksperimen dapat dilihat pada tabel 5 sebagai berikut.

Tabel 5

Rekapitulasi Persentase Hasil Observasi Aktivitas Siswa

\begin{tabular}{ccc} 
Indikator & Persentase & Interpretasi \\
\hline $\begin{array}{c}\text { Konstruktivisme } \\
\text { (Pengembangan } \\
\text { pikiran) }\end{array}$ & $91 \%$ & Sangat Baik \\
\hline $\begin{array}{c}\text { Menemukan } \\
\text { (Inkuiri) }\end{array}$ & $80 \%$ & Sangat Baik \\
\hline $\begin{array}{c}\text { Bertanya } \\
\text { (Pengembangan } \\
\text { rasa ingin tahu) }\end{array}$ & $68 \%$ & Baik \\
\hline $\begin{array}{c}\text { Masyarakat } \\
\text { Belajar }\end{array}$ & $98 \%$ & Sangat Baik \\
\hline Pemodelan & $97 \%$ & Sangat Baik \\
\hline Refleksi & $99 \%$ & Sangat Baik \\
\hline Penilaian & $96 \%$ & Sangat Baik \\
Beradasarkan & tabel 4.9
\end{tabular}

observasi aktivitas siswa

menunjukkan bahwa siswa antusias dalam melaksanakan proses pembelajaran. Hal ini terlihat jelas pada diagram 4.8 yang menunjukkan hasil persertase dari setiap indikator pendekatan CTL terinterpretasi sangat baik. Namun, aspek indikator bertanya (pengembangan rasa ingin tahu) yang mendapatkan persentase $68 \%$ sehingga hanya terinterpretasi baik. Hal ini menunjukkan bahwa penggunaan pendekatan CTL sangat mendukung berhasilnya pembelajaran. Dengan demikian, kemampuan pemahaman konsep IPA siswa pada kedua kelas dapat meningkat apabila aktivitas siswa selama proses pembelajaran mendukung dirinya untuk belajar.

\section{E. Kesimpulan}

Berdasarkan hasil analisis data dan pembahasan yang telah dipaparkan pada penjelasan di atas, maka kesimpulan dalam penelitian ini adalah terdapat pengaruh yang cukup besar terhadap kemampuan pemahaman konsep IPA siswa dalam pembelajaran menggunakan pendekatan CTL. Hal ini dibuktikan dengan nilai rata-rata siswa di kelas eksperimen ketika tes awal (prettest) sebesar 57, 71 dan ketika tes akhir (posttest) mencapai 72,71. Sedangkan di kelas kontrol pada tes 
awal (prettest) sebesar 64,00 dan setelah tes akhir (posttest) 54,16. Hal tersebut menunjukkan terdapat perbedaan yang signifikan antara nilai rata-rata pemahaman konsep IPA siswa sebelum dan sesudah menggunakan pendekatan CTL.

Setelah itu dapat dilihat dari perhitungan statistik yaitu hasil perhitungan uji-t kelas eksperimen dan kelas kontrol diperoleh nilai signifikasi 0,000. Karena 0,000 0,05 maka $\mathrm{H}_{0}$ ditolak. Hal ini menunjukkan bahwa terjadi perbedaan yang signifikan antara rata-rata nilai tes akhir kelas eksperimen dan kelas kontrol. Melihat rata-rata perbedaan kedua kelas tersebut maka dapat disimpulkan bahwa peningkatan kemampuan pemahaman konsep IPA siswa ketika menggunakan pendekatan CTL pada kelas eksperimen lebih tinggi di banding kelas kontrol. Hal ini membuktikan bahwa terdapat perbedaan yang cukup signifikan pada kemampuan pemahaman konsep IPA siswa di kelas eksperimen dengan menggunakan pendekatan CTL dengan kelas kontrol yang tidak menggunakan pendekatan CTL. Berdasarkan penjelasan diatas dapat disimpulkan bahwa penggunaan pendekatan CTL sangat berpengaruh terhadap pemahaman konsep IPA siswa.

\section{DAFTAR PUSTAKA}

Amir, M. F. (2015). PENGARUH PEMBELAJARAN

KONTEKSTUAL TERHADAP KEMAMPUAN PEMECAHAN MASALAH MATEMATIKA SISWA SEKOLAH DASAR. PROSIDING SEMINAR NASIONAL PENDIDIKAN, 3442. Diambil dari http://eprints.umsida.ac.id/330/

Anderson, L. W., \& Krathwohl, D. R. (2010). Kerangka landasan untuk pembelajaran, pengajaran, dan asesmen. Yogyakarta: Pustaka Pelajar, 300(300), 0.

Aqib, Z. (2013). Model-model, media, dan strategi pembelajaran kontekstual (inovatif). Bandung: yrama widya.

Aulia, N. I., \& Handayani, H. (2018). PENINGKATAN PEMAHAMAN KONSEP MATEMATIKA PESERTA DIDIK SEKOLAH DASAR MELLAUI MODEL PEMBELAJARAN TEAMS GAMES TOURNAMENT (TGT). JURNAL SILOGISME: Kajian IImu Matematika Dan Pembelajarannya, 3(3), 116120.

https://doi.org/10.24269/silogism e.v3i3.1475

Bybee, R. W. (2009). Program for International

Student Assessment (PISA) 2006 and Scientific Literacy: A Perspective 
for Science Education Leaders. Science Educator, 18(2), 1-13.

Campbell, D. T., \& Stanley, J. C. (2015). Experimental and quasiexperimental designs for research. Ravenio Books.

Hasibuan, M. I. (2015). MODEL PEMBELAJARAN CTL (CONTEXTUAL TEACHING AND LEARNING). Logaritma: Jurnal IImu-IImu Pendidikan Dan Sains, 2(01). https://doi.org/10.24952/logaritm a.v2i01.214

Hearron, P. F. (2000). THE DISCIPLINED MIND: What All Students Should Understand. Childhood Education, 76(3), 177-177.

Johnson, E. B. (2007). Contextual Teaching \& Learning, Menjadikan Kegiatan BelajarMengajar Mengasyikkan dan Bermakna (Terjemahan Ibnu Setiawan). Bandung: Penerbit MLC.

Krathwohl, D. R., \& Anderson, L. W. (2009). A taxonomy for learning, teaching, and assessing: $A$ revision of Bloom's taxonomy of educational objectives. Longman.

Margunayasa, I. G. (2014). Pengaruh Petunjuk Praktikum IPA Bermuatan Perubahan Konseptual Terhadap Peningkatan Pemahaman Konsep IPA Pada Mahasiswa PGSD. JPI (Jurnal Pendidikan Indonesia), 3(1).

Nurdyansyah, N. (2016). Developing ICT-Based Learning Model to Improve Learning Outcomes IPA of SD Fish Market in Sidoarjo. Jurnal TEKPEN, 1(2). Diambil dari

https://journal.unesa.ac.id/index. php/jtp/article/view/1137

Pendidikan, B. S. N. (2006). Kurikulum Tingkat Satuan Pendidikan. Jakarta: Departemen Pendidikan Nasional.

Permendiknas, R. I. (2006). No 22 Tahun 2006. Tentang Standar Isi untuk Satiuan Pendidikan Dasar dan Menengah". Jakarta: Depdiknas.

Rafika, R. (2014). Upaya Meningkatkan Pemahaman Konsep Gaya Dengan Menggunakan Metode Eksperimen Siswa Kelas IV SDN 1 Siwalempu. Jurnal Kreatif Online, 4(2). Diambil dari http://jurnal.untad.ac.id/jurnal/ind ex.php/JKTO/article/view/3331

Reigeluth, C. M., \& Moore, J. (1999). Cognitive education and the cognitive domain. Instructionaldesign theories and models: $A$ new paradigm of instructional theory, 2, 51-68.

Sanjaya, W. (2006). Strategi pembelajaran berorientasi standar proses pendidikan. Jakarta: kencana.

Singarimbun, M., \& Effendi, S. (1995). Metode Penelitian Survai Edisi Revisi. Jakarta: Lp3ES.

Slavin, R. E. (2011). Cooperative Learning: Teori dan Aplikasi PAIKEM. Pustaka Pelajar: Yogyakarta.

Suhana, C. (2014). Konsep strategi pembelajaran. Bandung: Refika Aditama.

Sujana, A. (2014). Pendidikan IPA teori dan praktik. Sumedang: Rizal Nur. 
Taufiq, M., Dewi, N. R., \& Widyatiningtyas, R. (2006). Widiyatmoko, A. (2014). Pengembangan media pembelajaran ipa terpadu berkarakter peduli lingkungan tema "konservasi" berpendekatan scienceedutainment. Jurnal Pendidikan IPA Indonesia, 3(2).

Uno, H. B. (2007). Model pembelajaran menciptakan proses belajar mengajar yang kreatif dan efektif. Jakarta: Bumi Aksara.

PEMBENTUKAN

PENGETAHUAN

TEKNOLOGI,

SAINS, MASYARAKAT PANDANGAN PENDIDIKAN IPA. EDUCARE, 1(2). Diambil dari

http://jurnal.fkip.unla.ac.id/index. php/educare/article/view/11

Wisudawati, A. W., \& Sulistyowati, E. (2014). Metodologi pembelajaran IPA. Jakarta: Bumi Aksara. 